\title{
Assessing the validity and reliability of creative thinking skills module in a pilot study on engineering undergraduate in Malaysia
}

\author{
Yaw Long, Chua ${ }^{1,2^{*}}$, Balamuralithara Balakrishnan ${ }^{2}$, \\ Voon Chiet, Chai ${ }^{3}$, Yit Yan, $\mathrm{Koh}^{4}$ \\ ${ }^{1}$ College of Engineering, Universiti Tenaga Nasional, Jalan Ikram-Uniten, Kajang, Selangor, Malaysia \\ ${ }^{2}$ Fakulti Seni, Komputeran dan Industri Kreatif, Universiti Pendidikan Sultan Idris, \\ Tanjong Malim, Perak, Malaysia \\ ${ }^{3}$ Heriot-Watt University Malaysia, No 1, Jalan Venna P5/2, Precinct 5, Putrajaya, Malaysia \\ ${ }^{4}$ Faculty of Engineering and Built Environment, University of Newcastle, Singapore, 6 Temasek \\ Boulevard, \#10-02/03, Suntec Tower 4, Singapore 038986 \\ *Corresponding email: chuayl@uniten.edu.my
}

Received: 06 April 2020; Accepted: 10 May 2020; Published: 21 May 2020

To cite this article (APA): Chua, Y. L., Balakrishnan, B., Chai, V. C., \& Koh, Y. Y. (2020). Assessing the validity and reliability of creative thinking skills module in a pilot study on engineering undergraduate in Malaysia. Asian Journal of Assessment in Teaching and Learning, 10(1), 78-86. https://doi.org/10.37134/ajatel.vol10.1.9.2020

To link to this article: https://doi.org/10.37134/ajatel.vol10.1.9.2020

\begin{abstract}
This research paper presents the outcome of a research conducted to assess and determine the Validity and Reliability coefficient of Creative Thinking Skills for Conceptual Engineering Design Module administered to engineering undergraduates at a private institution of higher learning. The Creative Thinking Skills Module features few proposed creative thinking tools such as Brain Sketching, Mind Maps and Morphological Analysis. The validity consists of module content validity, and session and activity validity, evaluated by a group of five experts. The Cronbach Alpha value was determined through conducting a pilot study in a local private university where mechanical engineering undergraduate underwent the module workshop and activity. Questionnaires were given to respective experts and students respondents to measure the validity and reliability level of the module, sessions and activities.
\end{abstract}

Keywords: Validity, Reliability, Cronbach Alpha, Creativity, Torrance Test of Creative Thinking, Engineering Education

\section{INTRODUCTION}

To ensure future engineers could cope with the ever-changing world and contribute positively in improving the world through innovative engineering solutions, the current generation of engineering students should be equipped with creativity on top of the technical knowledge that is taught in any engineering school. Engineers need to strike a balance between applying practical engineering knowledge and creativity in solving problems. Research urges universities to provide avenues for engineering students to nurture creativity (Baillie, 2002).

The engineering profession requires practitioners to acknowledge, validate and resolve problems individually or in a team (Liu \& Schönwetter, 2004). Creativity techniques are teachable and learnable, and these techniques are at the control of the individual Hewett (2005). Regrettably, educational institutions worldwide, including those in Malaysia, are not doing enough in supporting the cause of cultivating creativity (Brand, Hendy, \& Harrison, 2015; Robinson, 2013; Terkowsky \& Haertel, 2013; Haertel, Terkowsky, \& Jahnke, 2012; Daud, Omar, Turiman, \& Osman, 2012; Beghetto, 2010; Kazerounian \& Foley, 2007). To achieve developed nation status, Malaysia is certainly in need of a welldevised higher education curriculum that focuses not only on technical skills and knowledge, but also to prepare engineering students with practical skills such as creativity to ensure Malaysia can stay afloat, relevant remain competitive in the ever-changing global arena (Grapragasem, Krishnan, \& Mansor, 2014). 
Assessing the validity and reliability of creative thinking skills module in a pilot study on engineering undergraduate in Malaysia

This paper aims to examine the effect of the Creative Thinking Skills Module (CTSM) to improve the creativity of engineering undergraduates in Malaysia. Hence, the specific objectives of the study are as follows:

1. Determination of the validity of the CTSM module based on expert perspectives on the module content, module session and activity constructed based on Russell Model (1974).

2. Determination of Cronbach Alpha values of each session and activities of CTSM based on the results obtained through a pilot study in a local private university.

\section{LITERATURE REVIEW}

\section{Definition of Creativity}

Rhodes (1961) defined form of creativity categories into four different categories representing 4Ps, which are Process, Person, Press, and Product. Only the first category Process is involved in this research by adopting the Torrance Test of Creative Thinking (TTCT) as a measuring tool. According to Torrance (1974), creativity is defined as:

"A process of becoming sensitive to problems, deficiencies, gaps in knowledge, missing elements, disharmonies, and so on; identifying the difficult; searching for solutions, making guesses or formulating hypotheses about the deficiencies; testing and retesting these hypotheses and possibly modifying and retesting them, and finally communicating the results."

Figural creativity is of vital importance to engineer, as they are the person who designs their products mainly through sketches and drawings. The figural creativity ability can be measured using TTCT which measure the following abilities:

1. Fluency, which is the ability of the respondent to produce a large number of figural images;

2. Originality, which is the ability of the respondent to produce uncommon or unique responses;

3. Elaboration, which is the ability of the respondents to develop. Embroider, embellish, carry out, or otherwise elaborate on ideas;

4. Abstractness of Title, which is the ability of the respondent to synthesize and organize processes of thinking, capture the essence of the information involved, to know what is important and product good titles, and

5. Resistance to Premature Closure, which is the ability of the respondent to "keep open" and delay closure long enough to make the mental leap that makes original ideas possible.

Creativity was also considered as novel thinking, which sees problems redefined, gaps in knowledge identified, new ideas emerged, generated ideas analysed, and reasonable risks in idea development are taken. The ability for one to combine and connect ideas in new ways that are novel and useful has been widely accepted as the fundamental nature of creative thinking (Daly, Mosyjowski, \& Seifert, 2014). This ability is the perception of oneself as being creative and capable of creating creative solutions is an important factor that requires more attention. 


\section{METHODOLOGY}

A quantitative approach has been adopted in this research. The methodology is divided into three major areas:

1. CTSM Module Development

2. Application of External Criticism Validation by expert's method to find the validity of module content and validity of session and activity content

3. Conduct of a pilot study to determine the reliability of the module.

\section{Creative Thinking Skill Module Development}

A custom-tailored CTSM named Creative Thinking Skills for Conceptual Engineering Design was developed for Mechanical Engineering (ME) undergraduates. This module focuses on introducing, stimulating and enhancing creativity levels of ME undergraduates and to well prepare them for the industry. A total of seven different creative thinking skills are available in this module to stimulate creative thinking. The seven creative thinking skills are illustrated in Figure 1.

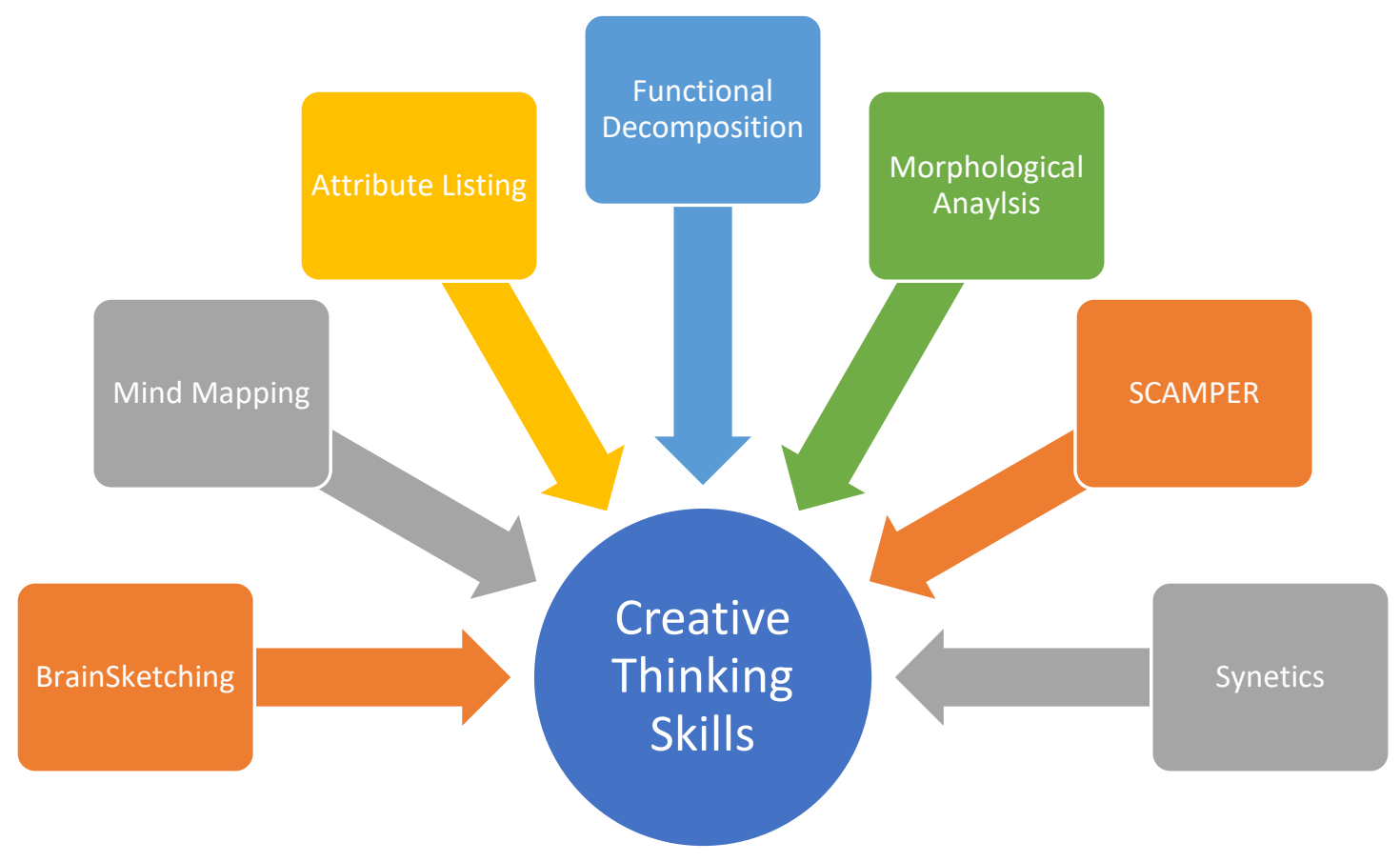

Figure 1. Seven Creative Thinking Skills in CTSM

\section{Determination of Module Validity}

Module validity refers to the accuracy of the concepts and contents of a module. The validity of external criticism method is applied and is determined in this research. This is because external criticism is one of the most effective methods of studying the validity of any research instrument (Fuad et al, 2019). For this research, the validity of the module content, and the validity of each session and activity are determined respectively. According to Russell (1974) method, the CTSM module content validity consists of five important items namely:

a) The contents of the module meet the population target;

b) The contents of the modules can be implemented perfectly; 
Assessing the validity and reliability of creative thinking skills module in a pilot study on engineering undergraduate in Malaysia

c) The contents of the module are compatible with time;

d) The contents of this module can improve individual creative thinking skills effectively;

e) The contents of this module can improve the students to a more brilliant direction.

The validity of each session and activity of the CTSM, on the other hand, is also determined separately according to every session and every activity in the module developed. There is a total of 9 sessions with different activities for each session. This means that the validity of the good CTSM must contain these features.

A set of validated questionnaires of module content validity, session and activity validity based on Russell's (1974) views were given to a group of appointed experts to determine the validity level of CTSM. The appointed group of experts' consist of five experts whose biodata are as illustrated in Table 1.

The scale for this validity assessment is from 1 to 10 , The scale of 1 is for strongly disagree up to 10 for strongly agree. To determine the level of validity of module content, session and activity, the total number of scores were filled by the experts, (x) will be divided by the actual total score (y), and multiplied by one hundred. A module has a high level of validity when it achieves $70 \%$ and is considered to have dominated or achieved a high level of achievement (Tuckman,1965; Sidek \& Jamaludin, 2005). The formula is as follows:

$$
\frac{\text { Expert Score Amount }(x)}{\text { Total Actual Score }(y)} \times 100 \%=\text { Level of Validity }
$$

Table 1. Biodata of the Expert Assessing the Validity of CTSM

\begin{tabular}{|c|c|}
\hline Expert Panel & Biodata of Expert Panel \\
\hline E1 & $\begin{array}{c}\text { More than } 10 \text { years of experience in lecturing Mechanical Engineering Degree and Diploma } \\
\text { Programmes } \\
\text { More than } 5 \text { years working overseas in Mechanical Engineering } \\
\text { Programme Leader of Mechanical Engineering Department of a Private University } \\
\text { Supervised more than 50 Bachelor Degree students }\end{array}$ \\
\hline E2 & $\begin{array}{c}\text { Former lecturer of a Private University } \\
\text { More than } 10 \text { years of experience in lecturing Mechanical Engineering Degree and Diploma } \\
\text { programmes } \\
\text { Supervised more than } 50 \text { Bachelor Degree Students } \\
\text { Currently Technical Director of a Private Company } \\
\text { Supervised more than } 10 \text { Mechanical Engineering intern students }\end{array}$ \\
\hline E3 & $\begin{array}{c}\text { Senior Lecturer in a Private University } \\
\text { More than } 10 \text { years of experience in lecturing Engineering Design related module such as } \\
\text { Machine Design } \\
\text { Supervised more than } 50 \text { Bachelor Degree students, Master and PhD students }\end{array}$ \\
\hline E4 & $\begin{array}{c}\text { Director of Teaching and Learning Unit of a Private University } \\
\text { More than } 5 \text { years of experience in lecturing Creative Thinking Module in a Private } \\
\text { University } \\
\text { More than } 10 \text { years of experience in providing training to tertiary educators. }\end{array}$ \\
\hline E5 & $\begin{array}{c}\text { Former Senior Lecturer of a Private University } \\
\text { More than } 10 \text { years of experience in lecturing Mechanical Engineering Degree programmes } \\
\text { Currently Technology Director of a Private Company } \\
\text { Appointed Principal Consultant of a Private Company }\end{array}$ \\
\hline
\end{tabular}

\section{Determination of Module Reliability}

Sidek and Jamaludin (2005) stated that the questionnaire created based on the objectives of a module or the implementation steps in the module can be used to determine the reliability of the module. This can be seen in a few successful cases reported recently. According to research conducted by Arip (2010), the module reliability is defined as the consistency and stability of a module in treating what should be treated as in the objectives of a module. The reliability determined will also be able to provide information to the 
researcher how well the students can follow the contents of the module (Russell, 1974).

The study by Arip (2010) has resulted in a set of the questionnaire where the items developed based on module implementation steps and it obtained a reliability coefficient value 0.838 . In another study by Ahmad et al. (2011), in the questionnaire developed using the module implementation steps, has obtained the reliability coefficient of 0.830 .

A set of questionnaires are set based on the objectives and activities of the module to test the reliability of CSTM. This set of questionnaires is completed by the respondents in the pilot study in a local private university after they followed and completed every activity. The scores obtained were analyzed to obtain the reliability value using Cronbach Alpha coefficient.

\section{Research Samples}

A pilot study was conducted in a local private university where $313^{\text {rd }}$ year Mechanical Engineering was involved. The students went through all the CTSM sessions and completed all the activities.

\section{RESULTS}

This section will provide the results of all the validity and reliability assessment from experts group and student respondents from the pilot study. The results are illustrated in Table 2, Table 3, Table 4, and Table 5 respectively.

\section{Module Content Validity Results}

Table 2 illustrates the results of the experts' validity assessment on the module content validity. The results in Table 2 show that for the module content validity with regards to statements related to perfect implementation, improving creative thinking skills, and improving the students to a more brilliant direction all scored $80 \%$ in average. Whereas, for the validity of module content with regards to the module being compatible with the allocated time scored the lowest in comparison with the others at $70 \%$.

Table 2. Module Content Validity of CTSM

\begin{tabular}{|c|c|c|c|c|c|c|c|c|}
\hline No & Item & E1 & E2 & E3 & E4 & E5 & Average & $\begin{array}{c}\text { Expert } \\
\text { View }\end{array}$ \\
\hline 1 & $\begin{array}{c}\text { The content of this module meets the population } \\
\text { target. }\end{array}$ & 90 & 60 & 80 & 80 & 80 & $78 \%$ & Accepted \\
\hline 2 & $\begin{array}{c}\text { The content of this module can be implemented } \\
\text { perfectly. }\end{array}$ & 80 & 70 & 80 & 80 & 90 & $80 \%$ & Accepted \\
\hline 3 & $\begin{array}{c}\text { This module is compatible with the allocated } \\
\text { time. }\end{array}$ & 80 & 80 & 80 & 70 & 40 & $70 \%$ & Accepted \\
\hline 4 & $\begin{array}{c}\text { The content of this module can improve } \\
\text { individual creative thinking skills effectively. }\end{array}$ & 80 & 70 & 80 & 100 & 80 & $80 \%$ & Accepted \\
\hline 5 & $\begin{array}{c}\text { The content of this module can improve the } \\
\text { students to a more brilliant direction. }\end{array}$ & 80 & 50 & 80 & 100 & 90 & $80 \%$ & Accepted \\
\hline
\end{tabular}

\section{Module Session and Activity Validity Results}

Table 3 illustrates the results of experts' assessment of CSTM session and activity validity. From the results portrayed in Table 3, the highest average for the validity of each session and activities of CTSM is at $84 \%$. Activity 2 for attribute listing and activity 1 and 2 for functional decomposition has the highest average for validity, where all 3 activities have the same average value of $84 \%$. On the lower end of the spectrum with only an average of $70 \%$ is activity 2 of Mind Mapping and activity 2 of Synetics. 
Assessing the validity and reliability of creative thinking skills module in a pilot study on engineering undergraduate in Malaysia

Table 3. Validity of Each session and Activities of CTSM

\begin{tabular}{|c|c|c|c|c|c|c|c|c|}
\hline Session & Activity/Session Descriptions & E1 & E2 & E3 & E4 & E5 & Average & Expert View \\
\hline 1 & $\begin{array}{c}\text { Introduction } \\
\text { Activity: Torrance Test of Creative } \\
\text { Thinking Figural Form A }\end{array}$ & 80 & 50 & 70 & 100 & 80 & $76 \%$ & Accepted \\
\hline 2 & $\begin{array}{c}\text { Brain Sketching } \\
\text { Activity 1: - Sketching Exercise }\end{array}$ & 80 & 60 & 70 & 90 & 90 & $78 \%$ & Accepted \\
\hline 3 & $\begin{array}{c}\text { Brain Sketching } \\
\text { Activity 2: - Design a new concept for a } \\
\text { car dashboard using Brain Sketching }\end{array}$ & 70 & 60 & 80 & 70 & 80 & $72 \%$ & Accepted \\
\hline 4 & $\begin{array}{c}\text { Mind-Mapping } \\
\text { Activity } 1-\text { True and False questions to } \\
\text { test the understanding of Mind-Map }\end{array}$ & 80 & 60 & 80 & 90 & 90 & $80 \%$ & Accepted \\
\hline 5 & $\begin{array}{c}\text { Mind-Mapping } \\
\text { Activity } 2 \text { - Construct a Mind Map given } \\
\text { topic on Renewable Energy: A Malaysian } \\
\text { Context }\end{array}$ & 90 & 60 & 70 & 60 & 70 & $70 \%$ & Accepted \\
\hline 6 & $\begin{array}{c}\text { Attribute Listing } \\
\text { Activity 1- Do you know what attributes } \\
\text { are? }\end{array}$ & 80 & 50 & 60 & 100 & 90 & $76 \%$ & Accepted \\
\hline 7 & $\begin{array}{c}\text { Attribute Listing } \\
\text { Activity } 2-\text { Listing down attributes of a } \\
\text { microwave oven } \\
\end{array}$ & 80 & 60 & 80 & 100 & 100 & $84 \%$ & Accepted \\
\hline 8 & $\begin{array}{l}\text { Functional Decomposition } \\
\text { Activity } 1-\text { Fill in the blanks. Do you } \\
\text { understand functional decomposition? }\end{array}$ & 80 & 70 & 80 & 100 & 90 & $84 \%$ & Accepted \\
\hline 9 & $\begin{array}{c}\text { Functional Decomposition } \\
\text { Activity } 2-\text { Functional Decomposition for } \\
\text { UNiRIDE electric bike available on } \\
\text { campus }\end{array}$ & 90 & 60 & 80 & 90 & 100 & $84 \%$ & Accepted \\
\hline 10 & $\begin{array}{l}\text { Morphological Analysis } \\
\text { Activity } 1 \text { - Describe your understanding } \\
\text { of functions in a short paragraph }\end{array}$ & 80 & 60 & 70 & 70 & 80 & $72 \%$ & Accepted \\
\hline 11 & $\begin{array}{c}\text { Morphological Analysis } \\
\text { Activity } 2 \text { - Idea generation using } \\
\text { morphological analysis: the new futuristic } \\
\text { concept of a bicycle. }\end{array}$ & 80 & 60 & 80 & 80 & 80 & $76 \%$ & Accepted \\
\hline 12 & $\begin{array}{c}\text { SCAMPER } \\
\text { Activity } 1 \text { - What do you understand } \\
\text { about SCAMPER? }\end{array}$ & 80 & 60 & 70 & 100 & 90 & $80 \%$ & Accepted \\
\hline 13 & $\begin{array}{c}\text { SCAMPER } \\
\text { Activity } 2-\text { Develop a new concept for an } \\
\text { office desk using SCAMPER }\end{array}$ & 80 & 60 & 80 & 80 & 60 & $72 \%$ & Accepted \\
\hline 14 & $\begin{array}{c}\text { Synectics } \\
\text { Activity } 1-\text { Analogy as a stepping stone } \\
\text { in Synectics }\end{array}$ & 80 & 60 & 80 & 80 & 80 & $76 \%$ & Accepted \\
\hline 15 & $\begin{array}{c}\text { Synectics } \\
\text { Activity } 2-\text { Given Topic on Public } \\
\text { Transportation, use Synectics to come out } \\
\text { with a creative approach of new public } \\
\text { transport concept for Malaysia }\end{array}$ & 80 & 50 & 80 & 70 & 70 & $70 \%$ & Accepted \\
\hline 16 & $\begin{array}{c}\text { Conclusion } \\
\text { Activity -Torrance Test of Creative } \\
\text { Thinking Figural Form B } \\
\end{array}$ & 80 & 30 & 80 & 100 & 80 & $74 \%$ & Accepted \\
\hline
\end{tabular}

\section{Module Reliability Results}

Module reliability questionnaires were provided to students to be filled up after they followed every session and activity in the module. The questionnaire was then analyzed to obtain the value of reliability 
by using Cronbach's Alpha coefficient method. The results of the value of the module overall reliability are illustrated in Table 4.

Table 4. Overall Reliability of CTSM

\begin{tabular}{|c|c|c|c|}
\hline $\mathbf{N}$ & Total Items & Alpha Value & Level \\
\hline 31 & 49 & 0.940 & High \\
\hline
\end{tabular}

Table 5 illustrates the results of the questionnaire of the CTSM based on all the sessions available in the module. The values at a significance level of 0.05 for Introduction is 0.811 , for Brain Sketching is 0.884 , for Mind Mapping is 0.823 , for Attribute Listing is 0.919, for Function Decomposition is 0.875, for Morphological Analysis is 0.822, for SCAMPER is 0.758, and for Conclusion is 0.932 . However, for Synetics, the Cronbach Alpha value is the lowest amongst all at only 0.677 .

Table 5. The values of Cronbach Alpha of the session and activities of CTSM

\begin{tabular}{|c|c|c|c|c|}
\hline Session & Description & No of Items & $\boldsymbol{\alpha}$ & Level/Decision \\
\hline Session 1 & Introduction & 4 & 0.811 & High/Accepted \\
\hline Session 2 & Brain Sketching & 6 & 0.884 & High/Accepted \\
\hline Session 3 & Mind Mapping & 6 & 0.823 & High/Accepted \\
\hline Session 4 & Attribute Listing & 6 & 0.919 & High/Accepted \\
\hline Session 5 & Functional Decomposition & 6 & 0.875 & High/Accepted \\
\hline Session 6 & Morphological Analysis & 6 & 0.822 & High/Accepted \\
\hline Session 7 & SCAMPER & 6 & 0.758 & High/Accepted \\
\hline Session 8 & Synetics & 6 & 0.677 & Low/Rejected \\
\hline Session 9 & Conclusion & 3 & 0.932 & High/Accepted \\
\hline
\end{tabular}

\section{DISCUSSION}

One of the aims in this study is to determine the Cronbach Alpha values of each session of CTSM based on the results obtained through a pilot study in a local private university, and hence to observe the effect of CTSM to improve the creativity.

According to Kerlinger (1979), having a value of $\alpha$ (alpha value) exceeds 0.6 at a significant level 0.05 is a good and recognized assessment. Chua (2013), a prominent researcher in Malaysia, on the other hand, mentioned that a Cronbach Alpha Value of 0.65 to 0.95 is satisfactory. Many of the researches are following a rule-of-thumb that alpha should reach a value of 0.70 for an instrument to qualify for an acceptable level of self-consistency (Taber, 2018). It should also be noted that alpha values of less than 0.70 may not always be considered as an indication of an unsatisfactory instrument, (Plummer \& Tanis Ozcelik, 2015). Adopted from Taber (2018), Figure 2 shows a graphical illustration of qualitative descriptors used for values/ranges of values of Cronbach's alpha, with an additional vertical line showing the indication of 0.70 of the "acceptable" value of the value of alpha. Despite the general 0.70 as acceptable values, it can also be seen that some authors would refer ranges of $0.60-0.70$ as "acceptable", "satisfactory", "sufficient", "reasonable", and "adequate".

This research confirmed that the CTSM possessed a high level of reliability coefficient value where the overall reliability of the module is well above the 0.60 level at 0.940 . For individual module session and activity reliability results, Conclusion has the highest alpha value at 0.932 , while the Synetics session has the lowest value of alpha at 0.677 . According to Konting (2000), when reliability value is high, the module developed has a good degree of consistency. The alpha values obtained and illustrated in Table 3 proved that all sessions conducted in CTSM are acceptable and reliable for use in interventions except for Synetics.

The validity of the CTSM is measured in two ways, that is module content validity, and module session and activity validity. The group of experts all gave high validity with regards to the module content, where the validity ranges fall within $70 \%$ to $80 \%$. This indicates that the module content is valid and can achieve the specific objectives set out by the module. The session and activity validity scores by the group of experts fall within $70 \%-84 \%$, which also illustrates that the session and activity are valid. This is in line with the threshold of validity as setting up and supported by Arip (2010) and Ahmad 
Jazimin, Abdul Malek, Mohammad Nasir dan Mohammad Aziz Shah (2011).

In general, this study presented the validity and reliability of the CTSM module to boost the creativity among the engineering undergraduates, and based on the judgements and views from the experts engaged in this research, the validity and reliability of this module are considered as high, which will be able to help undergraduates to further cope with engineering complexities.

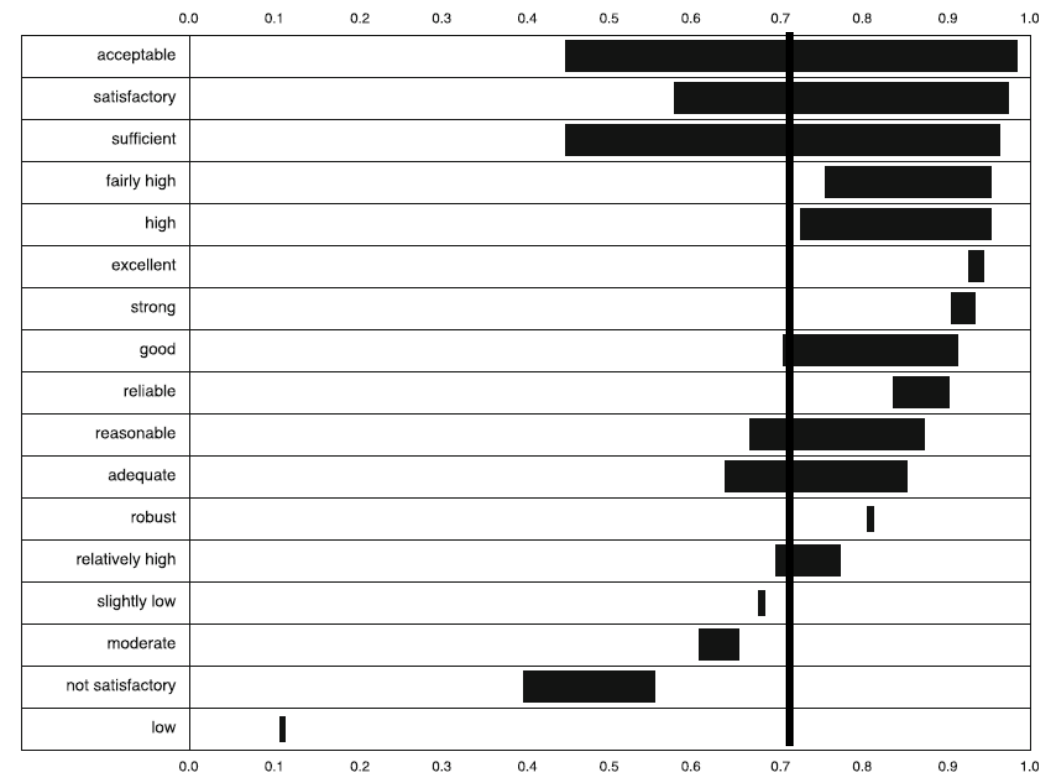

Figure 2: Figure adapted from Taber (2018), showing a graphical illustration of qualitative descriptors used for values/ranges of values of Cronbach's alpha.

\section{CONCLUSION}

In this research, the researcher developed a Creative Thinking Skills for Conceptual Engineering Designs module to address the issue of decline in Creativity that had been reported by many other researchers. The content of the module tested in terms of validity and followed by reliability by determining the Cronbach Alpha value. The major findings of the study are the success of the CTSM in obtaining acceptable validity from a group of five experts, and determination of reliability from the respondents. Based on the findings above, it can be concluded that Engineering undergraduate students can be trained or educated to be more creative when comes to deriving various relevant design of products or solutions.

The research findings also indicated that the Synetics session is probably unsuitable to be included as part of the skills in the module since the reliability is below the acceptable threshold of 0.7 . It is recommended that Synetcis be removed from the module and more time can be allocated for other skills sessions and activity.

The major findings also indirectly indicated that is a need for current engineering education providers to revamp or review the content of the Engineering programme and include creative thinking skills in their curriculum. It is important so that these future engineers will be able to identify the important information needed, to be able to identify the gap, to be able to search for creative solutions and to be able to present to his/her audience more creatively and effectively. The educators must also be aware that they need to generate engineers who can come up with abstract designs or solution that will most likely bring revolutionary changes. More attention should be given in this aspect so that the students can acquire this set of skill while still in university. 


\section{REFERENCES}

Ahmad J.J., Abdul M. A. R., Mohammad N. B. \& Mohammad A. S. A. (2011). Modul Kaunseling Kelompok CTRT: Pendekatan Menangani Permasalahan Disiplin Pelajar. Tanjung Malim. Penerbit UPSI.

Arip, M.A.S.M. (2010). Effect of group guidance on self-concept, resilience and adolescent aggression. [Unpublished PhD Thesis]. Bangi, Malaysia: National University of Malaysia.

Arip. M.A.S.M (2018). Pembinaan and PengujianModul. I Psychology and Counselling Academy.

Baillie, C. (2002). Enhancing creativity in engineering students. Engineering Science and Education Journal, 185192.

Beghetto, R. A. (2010). Creativity in the Classroom. In J. C. Kaufman, \& R. J. Sternberg, The Cambridge handbook of Creativity (pp. 447-463). Cambridge University Press.

Brand, G., Hendy, L., \& Harrison, R. (2015). Mining the Gap! Fostering Creativity and Innovative Thinking. The International Design Technology Conference, DesTech 2015 (pp. 79-84). Geelong Australia: Procedia Technology.

Chua, Y.P. (2013). Mastering Research Statistics. McGraw Hill Education. Malaysia

Daly, S., Mosyjowski, E., \& Seifert, C. M. (2014). Teaching Creativity in Engineering Courses. Journal of Engineering Education, 417- 449.

Daud, A. M., Omar, J., Turiman, P., \& Osman, K. (2012). Creativity in Science Education. UKM Teaching and Learning Congress 2011 (pp. 467-474). Procedia Social and Behavioral Science.

Fuad, R. A., Arip, M. A. S. M., \& Sa'ad, F. (2019). Validity and Reliability of the HM-Learning Module among High School Students in Malaysia. International Journal of Academic Research in Business and Social Sciences, 9(1), 773-787

Grapragasem, S., Krishnan, A., \& Mansor, A. N. (2014). Current Trends in Malaysian Higher Education and the Effect on Education Policy and Practice: An Overview. International Journal of Higher Education, 85- 93.

Haertel, T., Terkowsky, C., \& Jahnke, I. (2012). Where have all the inventors gone? Is There a Lack of spirit of research in engineering education curricula? 15th International Conference on Interactive Collaborative Learning and 41st International Conference on Engineering Pedagogy in Villach. Vienna.

Hewett, T. T. (2005). Informing the design of computer-based environments to support creativity. International Journal of Human-Computer Studies, 383-409.

Kazerounian, K., \& Foley, S. (2007). Barriers to Creativity in Engineering Education: A Study of Instructors and Students Perception. Journal of Mechanical Design, 761-768.

Kerlinger, F. N. (1979). Foundation of behavioural research. Ed. Ke-2. New York: Holt Rinehart \& Winston.

Konting, M. M. (2000). Research Methodology in Education. Kuala Lumpur: Dewan Bahasa dan Pustaka.

Liu, Z. C., \&Schönwetter, D. K. (2004). Teaching Creativity in Engineering Education. International Journal of Engineering Education, 801- 808.

Plummer, J. D., Tanis Ozcelik, A. (2015). Preservice teachers developing coherent inquiry investigations in elementary astronomy. Science Education, 99(5), (pp. 932-957). doi:10.1002/sce.21180.

Rhodes, J. M. (1961). An Analysis of Creativity. Phi Delta Kappan, 302-310

Robinson, S. K. (2013). Out of our minds. John Wiley.

Russell, J.D. (1974). Modular instruction: A guide to the design, selection, utilization and evaluation of modular materials. United States: Publishing Company.

Sidek, M.N., Jamaludin A., (2005).Module building: How to build exercise module and academic module, Serdang: University Putra Malaysia Publisher.

Taber, K. S. (2018). The Use of Cronbach's Alpha When Developing and Reporting Research Instruments in Science Education, Research in Science Education, 48 (pp. 1273-1296).

Terkowsky, C., \& Haertel, T. (2013). Where have all the inventors gone? IEEE Global Engineering Education Conference (EDUCON) (pp. 345-351). Berlin Germany: IEEE.

Torrance. (1974). Torrance Tests of Creative Thinking: Norms-Technical manual. Bensenville, IL: Scholastic Testing Services. 